\title{
Spring Wheat Response to Disease Control and Subsurface Drainage Management in the Red River of the North Valley, USA
}

\author{
Grant H. Mehring1*, Hans J. Kandel1, Joel K. Ransom¹, Amanda Schoch', Dean D. Steele ${ }^{2}$ \\ ${ }^{1}$ Department of Plant Science, North Dakota State University, Fargo, ND, USA \\ ${ }^{2}$ Department of Agricultural and Biosystems Engineering, North Dakota State University, Fargo, ND, USA \\ Email: "grant.mehring@ndsu.edu
}

Received 25 September 2015; accepted 23 October 2015; published 26 October 2015

Copyright (C) 2015 by authors and Scientific Research Publishing Inc.

This work is licensed under the Creative Commons Attribution International License (CC BY).

http://creativecommons.org/licenses/by/4.0/

(c) (i) Open Access

\begin{abstract}
Increased variability in rainfall events and high production input costs are driving agricultural producers to consider subsurface water management in the flat Red River of the North Valley in Eastern North Dakota and Northwestern Minnesota, USA. Subsurface tile incorporated with water table control structures was utilized from 2009 to 2011 to investigate the response of hard red spring wheat (HRSW) (Triticum aestivum L. emend. Thell.) for yield, disease, and other agronomic characteristics to soil water management. A factorial arrangement of four cultivars, two seed treatments, and two foliar fungicide treatments in a split-plot design with closed and open tile as whole-plots was used. Mean wheat yields averaged across years were not significantly different with closed or open tile treatments. There existed an optimum management practice where plant useable water was not freely drained and analyzing the data with the optimum water management for each year found the optimum water table managed treatment yielded higher with $3812 \mathrm{~g} \mathrm{ha}^{-1}$ compared with limited water table management with $3679 \mathrm{~kg} \mathrm{ha}^{-1}$. In 2011, the cultivars Faller and Howard were taller, and Traverse had lower root disease severity. In 2010 and 2011, Howard and Traverse had more leaf disease with open tile compared with closed tile. Across years, there was no difference in root disease, stand, number of spikes, crop height, or yield response to application of seed treatments with open or closed tile. In 2010, there was a $3.7 \%$ yield advantage with application of seed treatment on open tile. Across years, there was no yield response to application of foliar fungicides; however, wheat yield with foliar fungicide was $5 \%$ higher than without application in 2010. Producers should be using water table control and disease management to maximize HRSW yield. Further research should investigate water table management throughout the season based on weather conditions.
\end{abstract}

\footnotetext{
*Corresponding author.
}

How to cite this paper: Mehring, G.H., Kandel, H.J., Ransom, J.K., Schoch, A. and Steele, D.D. (2015) Spring Wheat Response to Disease Control and Subsurface Drainage Management in the Red River of the North Valley, USA. Agricultural Sciences, 6, 1220-1231. http://dx.doi.org/10.4236/as.2015.610117 


\section{Keywords}

\section{Spring Wheat, Disease Control, Subsurface Drainage, Water Table}

\section{Introduction}

Many different crops are grown in eastern North Dakota, in the USA, in an area known as the Red River Valley (RRV). The region is characterized as having a cold, sub-humid continental climate [1]. The RRV has level topography, and poorly-drained, clay-rich soils [2]. Fertile soil and favorable weather conditions have allowed North Dakota to occasionally rank first in the national production of wheat across market classes [3]. However, since the early 1990s the RRV has been in a wet climatic cycle, which has caused a decrease in crop yield potential due to increased disease pressure [4].

Surface drainage utilizing field ditches is the main method to alleviate excessive moisture conditions in the RRV [2]. In recent years the interest in subsurface tile drainage has increased, due to the wet climatic cycle and to help reduce the financial risk associated with high crop production input costs to farmers. Subsurface drainage tends to result in more stable production at a higher yield level [2].

For years subsurface drainage has been a common practice in many parts of the Upper Midwest, in the USA, but adoption of subsurface drainage into the RRV is relatively new. The slow adoption is largely due to the flat topography and limited natural outlets for subsurface drained systems [2]. Using subsurface drainage helps lower the water table and provides better soil aeration [5]. A lower water table causes soils to warm-up faster and potentially allows for earlier planting dates in cold and humid climates such as in the RRV. Soil temperature impacts seed germination, emergence, seedling growth, and soil microbial activity [6]. Subsurface drainage has also helped reduce soil compaction and decrease water-logging stress to plants [5]. Research has shown that subsurface drainage systems can increase grain yields, and improve soil trafficability and workability [7] [8].

In the USA there is an increased interest in managing the water table in subsurface drainage systems with control structures. Research on maize (Zea mays (L.)) and soybean (Glycine max (L.) Merrill) in Missouri has shown positive yield responses to controlled drainage and sub-irrigation [9]-[12]. However, research is still needed to address the agronomic impacts of subsurface drainage management on HRSW in the climatic and soil conditions of the RRV.

In susceptible wheat cultivars, fungal leaf spot diseases can cause reduced test weights and yield losses up to 50 percent [13]. Fusarium head blight (FHB), [Fusarium graminearum (Schwabe)], or scab, is another fungal disease that can cause significant yield loss in wheat [14] in addition to quality reductions [15].

Water-logged soils may cause root and crown rot in small grains [16] [17]. Phythium root rot (Pythium spp.) and take-all [Gaeumannomyces graminis (Sacc.)] are common in North Dakota. To help reduce the risk of crop injury and yield loss due to disease pressure, there are a number of effective management tools including crop rotation, residue management [13], seed treatments [18] [19], efficient timing of systemic fungicides [15], use of resistant cultivars [15], and possibly subsurface water management. Multiple tools should be utilized in a plant disease management strategy.

Studies conducted on hard red winter wheat observed that the application of fungicides at flowering (Zadoks 58) [20] improved yield and grain quality [15]. The yield increase was associated with the management of foliar leaf disease and FHB. The use of fungicides was profitable when applied to cultivars under high disease pressure, but not profitable when disease levels were low. Results showed that the combination of resistant varieties and fungicide application resulted in the highest yield and the greatest financial return [15].

With the wetter climatic cycle in the Northern USA and an increase in subsurface drainage management, producers are seeking additional management techniques to successfully grow HRSW. Previous researchers have not investigated the effect of subsurface drainage management, seed treatment, foliar application of fungicides and their interactions on yield, disease, and other agronomic characteristics in HRSW. The objectives of this research were to evaluate several HRSW cultivars' response to water table management with seed treatments, foliar applications of fungicides, and their interactions on selected plant characteristics, yield, and disease development when grown near Fargo. 


\section{Materials and Methods}

\subsection{Regional and Site Description}

The experiment was conducted in 2009, 2010, and 2011, at $46.932^{\circ} \mathrm{N}$ and $96.858^{\circ} \mathrm{W}$, near Fargo, ND. This site is situated in the RRV, which was once part of the glacial Lake Agassiz. The predominant soil at this site is FargoRyan silty clay. The Fargo series (fine, smectic, frigid, Typic Epiaquerts) consists of deep, poorly drained, slowly permeable, lacustrine soils. This soil generally has a slope of $0 \%$ to $1 \%$. The Ryan series (fine, smectic, frigid, Typic Natraquerts) is very similar to the Fargo series [21]. Soil analysis before the study began in 2009 for the 0 - $15 \mathrm{~cm}$ depth was $42 \mathrm{ppm} \mathrm{NO} \mathrm{NO}_{3} \mathrm{~N}, 13 \mathrm{ppm} \mathrm{P,} 426 \mathrm{ppm} \mathrm{K}, 7.7 \mathrm{pH}$ and $4.7 \%$ OM while the $15-70 \mathrm{~cm}$ depth had 563 ppm NO $\mathrm{N}_{3}-\mathrm{N}, 7 \mathrm{ppm} \mathrm{P}, 339 \mathrm{ppm} \mathrm{K}, 7.9 \mathrm{pH}$ and 3.4\% OM. The region has an annual average precipitation of $533 \mathrm{~mm}$ with 64\% of that occurring as rainfall from May to September [6]. Each year the previous crop was soybean.

The experimental design was a randomized complete block with four replicates in a split-plot arrangement where the main plots were open and closed subsurface tile drainage management and the sub-plots a $4 \times 2 \times 2$ factorial combination of cultivar, seed treatment, and in-season fungicide application.

The drainage treatment consisted of eight 0.33 -ha land units with independent subsurface water control structures (Agri Drain Corp, Adair, IA), which can set the drainage outlet height, and in effect the water table as described by Kandel et al. [8]. There were seven $102 \mathrm{~mm}$ diameter horizontal subsurface tile lines for each land unit with a spacing of $7.6 \mathrm{~m}$ apart and $100 \mathrm{~cm}$ tile depth and a main outlet to a drainage ditch located to the west of the units. Of these eight control structures four were kept closed (tile closed) to simulate non-subsurface drained conditions, while the other four were left open (tile open) to represent subsurface drained soil. The whole plot of open and closed subsurface tile drainage was analyzed statistically in two ways. Management level 1 was open and closed tile while management level 2 was best water table management practice. The outlet levels were set at 100, 90, and $85 \mathrm{~cm}$ below the surface in 2009, 2010, and 2011, respectively. Corresponding with a drainage coefficient of 8.4, 7.0, and $6.4 \mathrm{~mm}$ per $24 \mathrm{~h}$ for the 100,90 , and $85 \mathrm{~cm}$ below the surface settings, respectively. The outlet level in 2010 and 2011 was set closer to the surface based on the experimental results from 2009.

The wheat experimental plots (width $1.5 \mathrm{~m}$ and length $7.6 \mathrm{~m}$ ) consisted of seven rows at 18-cm row spacing and were seeded perpendicular to the tile lines and the center of the plot was on top of the tile line. Alleys $0.8-\mathrm{m}$ wide were later cut on the long ends between plots. The total harvested plot area was $1.5 \mathrm{~m} \times 5.8 \mathrm{~m}$. The seeding rate was 3 million pure live seeds ha ${ }^{-1}$. Two rain gauges were stationed at the research site to measure daily rainfall. Daily average temperature and precipitation data for each month during the growing season were collected by the Fargo automatic weather station $5 \mathrm{~km}$ away that is part of the North Dakota Agricultural Weather Network (Table 1) [1].

\subsection{Plant Materials}

Four HRSW cultivars and buffer strips ("Glenn"), on each side of the research area, were planted as early in the season as possible, using a Great Plains 3P605NT no-till plot drill (Great Plains Mfg Inc., Salina, KS). Cultivars

Table 1. Daily average temperature and precipitation for each month during the growing season in 2009 to 2011, Fargo, ND.

\begin{tabular}{|c|c|c|c|c|c|c|c|c|c|c|c|c|}
\hline \multirow[t]{2}{*}{ Month } & \multicolumn{4}{|c|}{ Max Air Temp } & \multicolumn{4}{|c|}{ Min Air Temp } & \multicolumn{4}{|c|}{ Precipitation } \\
\hline & 2009 & 2010 & 2011 & Avg. ${ }^{\dagger}$ & 2009 & 2010 & 2011 & Avg. & 2009 & 2010 & 2011 & Avg \\
\hline & \multicolumn{4}{|c|}{------- ${ }^{\circ} \mathrm{C}-------$} & \multicolumn{4}{|c|}{-------' ${ }^{\circ} \mathrm{C}-------$} & \multicolumn{4}{|c|}{--------mm------- } \\
\hline April & 10 & 18 & 11 & 13 & 1 & 4 & 2 & 0 & 16 & 37 & 46 & 35 \\
\hline May & 19 & 20 & 18 & 21 & 5 & 9 & 8 & 7 & 44 & 68 & 110 & 66 \\
\hline June & 24 & 25 & 24 & 25 & 12 & 14 & 14 & 13 & 82 & 86 & 101 & 89 \\
\hline July & 26 & 28 & 29 & 28 & 13 & 17 & 18 & 15 & 16 & 105 & 104 & 73 \\
\hline August & 25 & 28 & 28 & 27 & 13 & 16 & 16 & 14 & 47 & 68 & 73 & 64 \\
\hline Total & & & & & & & & & 205 & 364 & 434 & 327 \\
\hline
\end{tabular}

${ }^{\dagger} \mathrm{Avg}$. is 30-year average (1971-2000) [11]. 
were selected based on their variable response to leaf disease, FHB, and other characteristics (Table 2) [22] [23].

Fertilizer $\mathrm{P}$ and $\mathrm{K}$ was applied in the fall the year before seeding based on soil tests. In addition fertilizer $\mathrm{N}$ was applied as urea (46-0-0) at a rate of $112 \mathrm{~kg} \cdot \mathrm{N} \cdot \mathrm{ha}^{-1}$ in the spring using a Gandy 10T Series fertilizer spreader (Gandy Company, Owatonna, MN), for a yield goal of $4500 \mathrm{~kg} \mathrm{ha}^{-1}$ [24]. In 2010 an additional $56 \mathrm{~kg} \cdot \mathrm{N} \cdot \mathrm{ha}^{-1}$ as urea was surface applied with a Gandy 1.2 m Nursery Special (Gandy Company, Owatonna, MN). This second application was done 07 June at the boot stage (Zadoks 45) because signs of leaf yellowing were present. Dates for field operations are provided in Table 3.

Before planting, seed receiving the seed treatment were treated with Tebuconazole: Alpha-[2-(4-chlorophenyl)ethyl]-alpha-(1,1-dimethyl-ethyl)-1H-1,2,4-triazole-1-ethanol and Metalaxyl: N-(2,6-dimethylphenyl)-N(methoxyacetyl) alanine methyl ester; formulated as Raxil MD, (Bayer CropScience, Research Triangle Park, NC) applied at rate of $3.78 \mathrm{~g} / \mathrm{ai} 100 \mathrm{~kg}^{-1}$. Seed was treated using a Hege II batch seed treatment machine (Waldenburg, Germany). Foliar fungicide in-season treatment consisted of no fungicide or fungicide at anthesis (Zadoks 60). The fungicide used was Prothioconazole: 2-[2-(1-Chlorocyclopropyl)-3-(2-chlorophenyl)-2-hydroxypropyl]-1,2-dihydro-3H-1,2,4-triazole-3-thione and Tebuconazole: alpha-[2-(4-chlorophenyl)ethyl]-alpha-(1,1dimethylethyl)-1H-1,2,4-triazole-1-ethanol; formulated as Prosaro 421 SC, (Bayer CropScience, Research Triangle Park, NC) at rate of $252.2 \mathrm{~g} \cdot \mathrm{ai} \mathrm{ha}^{-1}$ in $93.5 \mathrm{~L} \mathrm{ha}^{-1}$ water at $200 \mathrm{kPa}$ using XR TEEJET $8001 \mathrm{VS}$ nozzles. North Dakota Extension Service recommended fungicide application techniques were used [25]. Weeds were controlled with an application of Fenoxaprop-p-Ethyl, Pyrasulfotole, Bromoxynil Octanoate, and Bromoxynil Heptanoate; formulated as Wolverine (Bayer CropScience, Research Triangle Park, NC) at a rate of $2 \mathrm{~L} \mathrm{ha}^{-1}$ equal to $272 \mathrm{~g} \cdot \mathrm{ai} \mathrm{ha}^{-1}$, at the four-leaf stage (Zadoks 14).

\subsection{Plant Observations and Disease Assessment}

Plant stand was determined at the two-leaf stage (Zadoks 12) by counting a random 30-cm length of row from rows two and six and averaging to determine plants ha ${ }^{-1}$. Spike count, after anthesis (Zadoks 69) (2010-11 only) was determined by counting spikes in $91 \mathrm{~cm}$ of rows two and six and averaging to determine spikes ha ${ }^{-1}$. Crop

Table 2. Characteristic of hard red spring wheat cultivars used in 2009 to 2011, Fargo, ND.

\begin{tabular}{cccccccc}
\hline & Height $^{\dagger}$ & Days to Heading & Stem Rust $^{\ddagger}$ & Leaf Rust $^{\ddagger}$ & Foliar Disease $^{\ddagger \S \S}$ & Fusarium Head Blight $^{\ddagger}$ & Straw Strength $^{\uparrow}$ \\
\hline cm & DAP & $1-9$ & $1-9$ & $1-9$ & $1-9$ & $1-9$ \\
\hline Faller $^{\dagger \dagger}$ & 81 & 54 & 1 & 1 & 3 & 4 & 5 \\
Howard $^{\dagger \dagger}$ & 84 & 52 & 1 & 1 & 4 & 6 & 7 \\
Sabin $^{\ddagger \ddagger}$ & 76 & 53 & 1 & 3 & 6 & 4 & 6 \\
Traverse $^{\S \S}$ & 85 & 51 & 2 & 5 & 5 & 5 & 6
\end{tabular}

${ }^{\dagger}$ Sources: [1] [18]. ${ }^{\ddagger} 1$ - 9 scale where 1 = most resistant, 9 = most susceptible. ${ }^{\S}$ Includes tan spot, septoria, bacterial leaf blight, and powdery mildew.

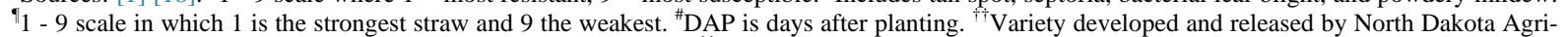
cultural Experiment Station, including buffer strip variety Glenn. ${ }^{\ddagger \ddagger}$ Variety developed and released by University of Minnesota Agricultural Experiment Station. ${ }^{\S \S}$ Variety developed and released by South Dakota Agricultural Experiment Station.

Table 3. Dates of field operations in 2009 to 2011, Fargo, ND.

\begin{tabular}{llll}
\hline Operation & 2009 & 2010 & 2011 \\
\hline Fertilizing & 08 May & 28 April & 19 June \\
Seeding & 11 May & 12 April & May \\
Stand count & 27 May & 04 Maye & 09 June \\
Herbicide application & 09 June & 18 May & 04 July \\
Fungicide application & 09 July & 18 June & 05 August \\
Harvest & 24 August & 10 August \\
\hline
\end{tabular}


height measurement was taken twice per plot and averaged, (2010-11 only) before harvest from ground level to the top of the spike, excluding the awns.

Crown root rot ratings were based on the extent of lesion development on the sub-crown internodes and mesocotyl [26]. Five plants were randomly selected in each plot at the soft dough stage (Zadoks 85) and cleaned by wiping soil away on the mesocotyl. Disease scores were then assigned as a percent of mesocotyl discolored [27].

Leaf disease notes were taken when plants were at the soft dough stage (Zakoks 85). The combined level of severity of leaf rust and leaf spot diseases (tan spot and septoria) were visually estimated based on percent disease covering the flag leaf. Five random flag leaf samples were evaluated and data averaged.

Fusarium head blight was estimated from ten randomly selected spikes at ripening (Zakoks 90). The intensity was assessed as the number of spikes infected with FHB and the severity as the percentage of the spike damaged by FHB [28].

Plots were harvested with a small plot combine. The harvested grain was then dried and cleaned with a Clipper office tester and cleaner (Seedburo Equipment Co., Chicago, IL) and weighed. Harvest moisture and test weight were recorded with a Dickey-John GAC 2100 (Dickey-John Corp., Minneapolis, MN). Yield was adjusted to reflect $13 \%$ grain moisture content.

\subsection{Water Table Depth}

Water table depths were measured for a whole plot effect of closed and open tile. Within each of the eight units, four observation wells midway between adjacent subsurface drain lines near the center of each unit were used to measure the water table depth below the soil surface. The wells consisted of vertically installed pipes $122 \mathrm{~cm}$ and $213 \mathrm{~cm}$ deep. The depth to the water table was measured using a Solinst water level meter (Model 101, Solinst, Georgetown, ON, Canada). Water table depths were recorded from the soil surface to the top of the water table. Recorded water depths were averaged across each drainage treatment.

\subsection{Statistical Analysis}

For each year, the statistical analysis was performed utilizing standard procedures for a randomized complete block design with a split-plot arrangement for closed versus open tile. If the error mean square between the years was homogenous, then a combined analysis across years was conducted for that trait. In 2009, the closed water structure was holding back water in the middle of July which would have been the best water management practice for that year due to dry growing conditions. For 2010 and 2011 open control structures were the best water management practice due to wetter conditions. These observations led us to consider the two water table management levels for statistical analysis of the yield data combined across years. In management level 1, a combined analysis of closed tile versus open tile treatments was conducted with no consideration of the setting of the water table position in the control structure. In management level 2, we analyzed the best water table management practice compared with the other treatment, where the best management treatment was closed tile in 2009 and open tile in 2010 and 2011. The best water management treatment for level 2 was responsive to in-season weather and water table position.

For the statistical analysis, tile or water management, cultivar, seed treatment, and fungicide were considered fixed effects. Years and replicates were considered random effects and all interactions of fixed effects with year or replicate were considered random. Data analysis was conducted using the mixed model procedure (PROC MIXED) of SAS version 9.3 (SAS Institute, SAS Circle, Cary, NC). Treatment means were separated using the PDIFF function under the LSMEANS statement at an alpha of 0.10 level of significance for each evaluated characteristic.

\section{Results and Discussion}

\subsection{Rainfall, Temperature and Water Table}

\subsubsection{9}

The summer of 2009 was relatively dry (Table 1) with only 63\% of the long-term precipitation, and cooler than normal. There were no rainfall events intense or large enough to produce surface runoff events at the trial location. From the 11 May seeding through 01 July the water table was below the tile line. After repeated rainfall events at the end of June the water table rose above the tile line in both treatments. With the open tile there was 
limited drainage from 01 July through 08 July (early to late boot stage, Zadok 45 - 49). With the control structure closed the water was retained and the water table was $12 \mathrm{~cm}$ higher than the water table in the open tile treatment for a portion of July (Figure 1(a)). For the rest of the season the water table was below the tile line.

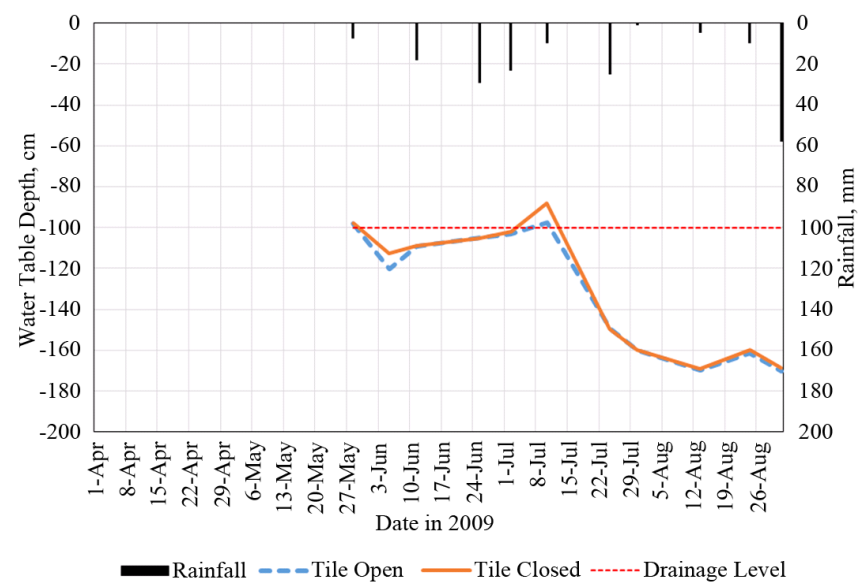

(a)

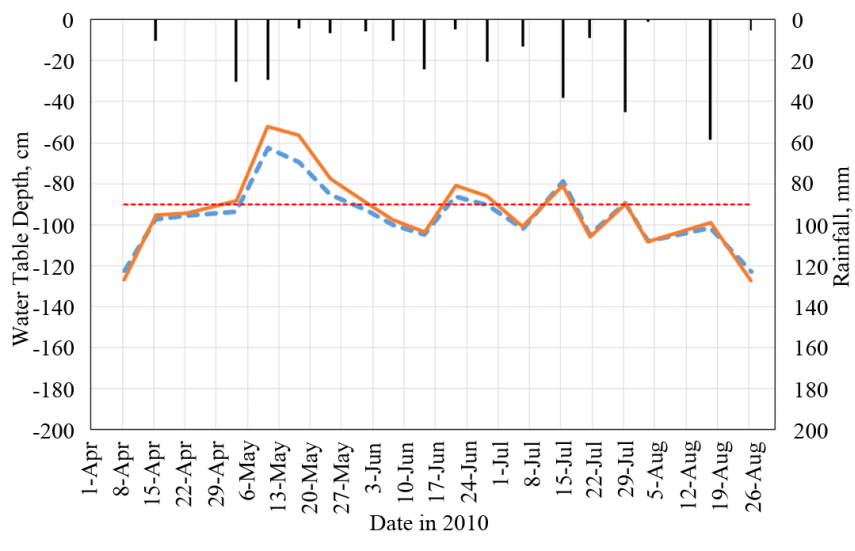

Rainfall ---Tile Open —Tile Closed -------Drainage Level

(b)

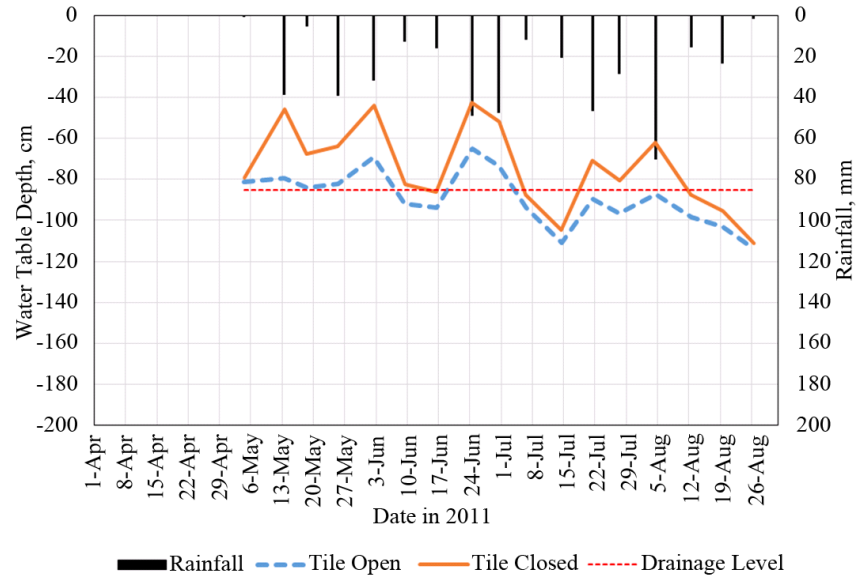

(c)

Figure 1. (a) Water table depth and rainfall in 2009, Fargo, ND. (b) Water table depth and rainfall in 2010, Fargo, ND. (c) Water table depth and rainfall in 2011, Fargo, ND. 


\subsubsection{0}

The temperature in April was higher than normal and the HRSW was seeded by the middle of April. The average maximum temperature was close to normal but the night (minimum temperatures) was above average during the growing season. Rainfall was close to normal for all months except July when there was $40 \%$ more precipitation than normal (Table 1). The water table was below the tile line until about 06 May. The open tile plots were releasing water through 01 June. The water table in the open tile situation was consistently deeper than the closed tile treatment. In the closed tile treatment the water table reached a level of $52 \mathrm{~cm}$ below the surface on 10 May (Figure 1(b)) and the wheat was in the three leaf stage (Zadok 13).

\subsubsection{1}

The early summer of 2011 was relatively cool with below average maximum temperatures for April and May. The weather turned hot during flowering and grain fill. Every month of the growing season had higher precipitation levels than the normal, resulting in about 30\% more rainfall during the growing season (Table 1 ). The water table with the control structure open was consistently deeper than the water table with closed tile. In the closed situation the water table reached a level of about $44 \mathrm{~cm}$ below the soil surface (Figure 1(c)) on 13 May (plants just emerged, Zadok 10), 13 June (four leaf stage, Zadok 14) and June 24 (early boot, Zadok 44 - 25).

\subsubsection{Yield}

Wheat yield with open tile was not significantly different $($ at $\mathrm{P} \leq 0.10)$ from the yield with the control structure closed (Table 4 and Table 5). This corresponds with management level 1 where no adjustment of the control structures was made in response to precipitation or water table. These results are similar to equal HRSW yields reported by Wiersma et al. [2] for tiled and non-tiled treatments and equal winter wheat yields reported by Poole

Table 4. Probability level of significance for yield with tile open in control boxes versus closed, for individual years, combined 2009 to 2011 and for the best management strategy for water table management combined in 2009 to 2011, Fargo, ND.

\begin{tabular}{|c|c|c|c|c|c|c|}
\hline & & & & & Management & Management \\
\hline & & & & & Level $1^{\dagger}$ & Level $2^{\ddagger}$ \\
\hline & & 2009 & 2010 & 2011 & $\begin{array}{c}\text { Closed vs Open } \\
2009-2011\end{array}$ & $\begin{array}{c}\text { Best Managed } \\
2009-2011\end{array}$ \\
\hline Sources of Variation & $\mathrm{df}$ & \multicolumn{5}{|c|}{------------------Probability > F-------------------- } \\
\hline Closed vs Open Tile (Main) & 1 & 0.19 & 0.74 & 0.18 & 0.97 & $0.08^{\S}$ \\
\hline Cultivar & 3 & 0.01 & $<0.0001$ & 0.02 & 0.49 & 0.50 \\
\hline Main $\times$ Cultivar & 3 & 0.59 & 0.52 & 0.09 & 0.29 & 0.99 \\
\hline Seed Treatment (ST) & 1 & 0.15 & 0.74 & 0.14 & 0.12 & 0.12 \\
\hline Main $\times$ ST & 1 & 0.22 & 0.09 & 0.06 & 0.66 & 0.72 \\
\hline Cultivar $\times$ ST & 3 & 0.52 & 0.70 & 0.29 & 0.34 & 0.34 \\
\hline Main $\times$ Cultivar $\times$ ST & 3 & 0.02 & 0.57 & 0.73 & 0.49 & 0.46 \\
\hline Foliar Fungicide (FF) & 1 & 0.45 & $<0.0001$ & 0.49 & 0.41 & 0.41 \\
\hline Main $\times$ FF & 1 & 0.79 & 0.23 & 0.53 & 0.59 & 0.87 \\
\hline Cultivar $\times$ FF & 3 & 0.90 & 0.40 & 0.43 & 0.41 & 0.41 \\
\hline Main $\times$ Cultivar $\times$ FF & 3 & 0.62 & 0.65 & 0.92 & 0.92 & 0.29 \\
\hline $\mathrm{ST} \times \mathrm{FF}$ & 1 & 0.53 & 0.07 & 0.07 & 0.05 & 0.05 \\
\hline Main $\times \mathrm{ST} \times \mathrm{FF}$ & 1 & 0.76 & 0.12 & 0.24 & 0.10 & 0.32 \\
\hline Cultivar $\times \mathrm{ST} \times \mathrm{FF}$ & 3 & 0.55 & 0.43 & 0.79 & 0.13 & 0.13 \\
\hline Main $\times$ Cultivar $\times$ ST $\times$ FF & 3 & 0.81 & 0.29 & 0.85 & 0.04 & 0.61 \\
\hline
\end{tabular}

${ }^{\dagger}$ Level 1 is closed or open tile. ${ }^{\ddagger}$ Level 2 is a best management approach, i.e., tile closed in 2009 in response to dry conditions and tile open in 2010 and 2011 in response to wetter conditions. ${ }^{\S}$ Bold numbers indicate significance at $P \leq 0.10$. 
Table 5. Hard red spring wheat yield with closed and open tile as whole plot factors and with limited management and best management as whole plot factors in 2009 to 2011, Fargo, ND.

\begin{tabular}{|c|c|c|c|c|c|c|}
\hline Management Level $1^{\dagger}$ & 2009 & 2010 & 2011 & 2009-2011 & Management Level $2^{\ddagger}$ & 2009-2011 \\
\hline \multicolumn{6}{|c|}{ 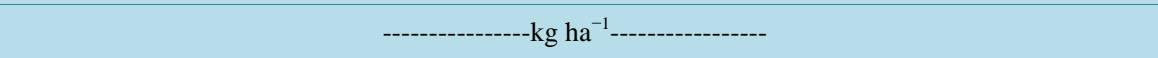 } & --kg ha ${ }^{-1}-$ \\
\hline Closed tile & $4696 \mathrm{a}^{\S}$ & $4155 \mathrm{a}$ & 2378 a & 3743 a & Limited management & $3679 \mathrm{~b}$ \\
\hline Open tile & $4504 \mathrm{a}$ & $4211 \mathrm{a}$ & 2528 a & 3748 a & Best Management & 3812 a \\
\hline
\end{tabular}

${ }^{\dagger}$ Level 1 is closed or open tile. ${ }^{\ddagger}$ Level 2 is a best management approach, i.e., tile closed in 2009 in response to dry conditions and tile open in 2010 and 2011 in response to wetter conditions. ${ }^{\S}$ Numbers within the same column with the same letter are not significantly different at $P \leq 0.10$.

et al. [29]. Evaluating the individual years we noticed that in 2009 yield with closed tile was numerically higher than the open tile, but the opposite in 2010 and 2011. Poole et al. [29] reported non-significant increase in winter wheat yields in 2 out of 4 environments with controlled drainage versus free drainage. They concluded that yield gains were higher when water was beneficially held back during dry periods and losses were found when water was held back past the optimum water level. The data from Wiersma et al. [2] indicated a non-significant numerical HRSW yield increase of about 4\% with drained plots with drainage coefficients of 6.3 and 12.7 $\mathrm{mm} / \mathrm{d}^{-1}$ compared to the control (no subsurface drainage) in seven environments over four years. However, a 19 $\mathrm{mm} / \mathrm{d}^{-1}$ coefficient resulted in identical yield with the control. This seems to indicate that plant useable water removal may negate potential positive effects of drainage. With excess moisture at the wrong growth stage crop yields may be decreased but there also may be periods in the growing season that a crop benefits from additional stored water via controlled drainage [29].

During 2009 there was some water kept above the tile line with the control structure closed (Figure 1(a)). There was no excess water stress in 2009 from other rainfall events so the closed control structure represents the best management practice and mimics setting the tile control structure at $90 \mathrm{~cm}$ below the surface level. We set the control structure at $90 \mathrm{~cm}$ in 2010, and $85 \mathrm{~cm}$ below the surface level in 2011. In 2010 and 2011, with managed control structure levels, there was excess precipitation during the growing season and water was released from the field (Figure 1(b) and Figure 1(c)). Combining the best management practices of retaining water in 2009 while releasing water in both 2010 and 2011 resulted in a significant yield increase (Table 4 and Table 5). This represents management level 2 where a control structure would remain closed during dry conditions and open when drainage needed to occur. The results indicate that under dry conditions like 2009 completely open tile may result in lower yields because of the drainage of crop usable water. It also indicates that subsurface water management through a control structure can provide the option to set the water table and conserve plant usable water. To our knowledge this is the first report indicating the importance of managing the water table with a control structure instead of using uncontrolled subsurface drainage in HRSW. Our findings seem to correspond with Nelson et al. [9], who found that soybean yield for certain varieties was higher with the combination of subsurface drainage and irrigation compared with subsurface drainage alone.

\subsubsection{Tile $\times$ Cultivar}

There were only significant interactions between tile treatments and cultivars for yield in 2011, height in 2011, root disease in 2010, and leaf disease in 2010 to 2011, respectively (Table 6). In 2011, the yield of Faller with open tile was significantly higher compared with closed tile. Faller and Howard were significantly taller with open tile compared with closed tile in 2011. In 2010, Traverse had less root disease with open tile compared with closed tile. There were significant differences between cultivars for leaf disease. Across 2010-2011, both Howard and Traverse had more leaf disease with open tile compared with closed tile (Table 6). Traverse had the highest percent leaf disease of the cultivars under open tile. This cultivar was included because of susceptibility to leaf rust and other foliar diseases (Table 2). It may be possible that the taller Howard plants under open tile conditions had a different micro environment resulting in higher leaf disease levels compared with the closed tile condition. However, plant height for Traverse did not differ between closed and open tile (Table 6).

\subsubsection{Tile $\times$ Seed Treatment}

There was no interaction between the tile and seed treatments for yield in the combined analysis (Table 4 and Table 7). The yield with open tile and seed treatment, was 3.7\% higher yielding compared with closed tile and 
Table 6. Yield, plant height, root disease and leaf disease ratings for cultivars with closed and open tile in 2010 to 2011, Fargo, ND.

\begin{tabular}{cccccc}
\hline & & 2011 & 2011 & 2010 & 2010 \\
\hline \multirow{2}{*}{ Tile } & Cultivar & yield & height & disease & disease \\
& & & & & to 2011 \\
\hline \multirow{2}{*}{ Closed } & Faller & $2198 \mathrm{~d}^{\dagger}$ & $77.8 \mathrm{c}$ & $0.7 \mathrm{c}$ & $6.9 \mathrm{c}$ \\
Closed & Howard & $2386 \mathrm{bc}$ & $78.0 \mathrm{c}$ & $5.4 \mathrm{~b}$ & $4.0 \mathrm{e}$ \\
Closed & Sabin & $2312 \mathrm{c}$ & $75.9 \mathrm{c}$ & $2.9 \mathrm{bc}$ & $4.4 \mathrm{de}$ \\
Closed & Traverse & $2616 \mathrm{a}$ & $86.0 \mathrm{a}$ & $10.2 \mathrm{a}$ & $7.8 \mathrm{~b}$ \\
Open & Faller & $2501 \mathrm{abc}$ & $81.9 \mathrm{~b}$ & $1.0 \mathrm{c}$ & $6.2 \mathrm{c}$ \\
Open & Howard & $2547 \mathrm{ab}$ & $81.3 \mathrm{~b}$ & $1.8 \mathrm{bc}$ & $5.1 \mathrm{~d}$ \\
Open & Sabin & $2518 \mathrm{abc}$ & $75.7 \mathrm{c}$ & $1.0 \mathrm{c}$ & $4.9 \mathrm{~d}$ \\
Open & Traverse & $2546 \mathrm{ab}$ & $86.4 \mathrm{a}$ & $3.1 \mathrm{bc}$ & $8.7 \mathrm{a}$ \\
\hline \multirow{2}{*}{ Interaction } & & & --- Probability & $>$ F----- & \\
\hline
\end{tabular}

${ }^{\dagger}$ Numbers within the same column with at least one similar letter are not significantly different at $P \leq$ 0.10 .

Table 7. Hard red spring wheat yield, plant stand, spikes, height, root disease and Fusarium head blight incidence with closed and open tile, without and with seed treatments in 2009 to 2011, Fargo, ND.

\begin{tabular}{|c|c|c|c|c|c|c|c|c|c|c|}
\hline & & 2009 & 2010 & 2011 & 2009 & 2009-11 & $2010-11$ & 2010-11 & 2010-11 & 2010-11 \\
\hline & & & & & to 2011 & Plant & & Plant & Root & Fusarium \\
\hline \multirow[t]{2}{*}{ Tile } & Seed treatment & \multicolumn{4}{|c|}{------------------Seed yield--------------- } & stand & Spikes & height & disease & incidence \\
\hline & & \multicolumn{4}{|c|}{-----------------kg ha ${ }^{-1}$------------------ } & million ha ${ }^{-1}$ & million ha ${ }^{-1}$ & $\mathrm{~cm}$ & $\%$ & $\%$ \\
\hline Closed & No seed treatment & $4604 \mathrm{a}^{\dagger}$ & $4193 \mathrm{ab}$ & $2289 \mathrm{~b}$ & 3695 a & $2.52 \mathrm{a}$ & 3.69 a & $67.0 \mathrm{a}$ & $10.3 \mathrm{a}$ & $12.3 \mathrm{~b}$ \\
\hline Closed & Seed treatment & 4789 a & $4117 \mathrm{~b}$ & 2468 a & 3791 a & $2.51 \mathrm{a}$ & $3.91 \mathrm{a}$ & $69.7 \mathrm{a}$ & 6.2 a & $12.5 \mathrm{~b}$ \\
\hline Open & No seed treatment & 4497 a & $4157 \mathrm{ab}$ & 2538 a & 3731 a & $2.61 \mathrm{a}$ & $3.61 \mathrm{a}$ & $71.8 \mathrm{a}$ & $9.0 \mathrm{a}$ & $16.4 \mathrm{a}$ \\
\hline Open & Seed treatment & 4511 a & 4270 a & 2518 a & 3766 a & $2.53 \mathrm{a}$ & $3.65 \mathrm{a}$ & $72.4 \mathrm{a}$ & $8.4 \mathrm{a}$ & $14.2 \mathrm{ab}$ \\
\hline
\end{tabular}

${ }^{\dagger}$ Numbers within the same column with at least one similar letter ar not significantly different at $P \leq 0.10$.

seed treatment in 2010. In 2011, open tile without seed treatment was 11\% higher yielding than closed tile without seed treatment (Table 7). Cook et al. [30] reported an increase in yield under severe root disease pressure with certain seed treatment combinations that were effective in controlling root disease.

There was no tile by seed treatment interaction and no differences in plant stand, spikes, or plant height (Table 7). The 2009 growing season was dry and FHB and root disease were minimal and therefore, only 2010 to 2011 data are reported. The tile by seed treatment interaction for FHB incidence was significant with higher incidence of FHB when tile was open compared with when it was closed for no seed treatments (Table 7). We expected that open tile would have lower FHB with a lower water table. Possibly there was a difference in the canopy structure and airflow as the HRSW cultivars Faller and Howard were taller on open tile compared with closed tile (Table 6). 


\subsubsection{Tile $\times$ Foliar Fungicide}

In 2010, HRSW with foliar fungicide yielded significantly (Table 4) more at $4286 \mathrm{~kg} \mathrm{ha}^{-1}$ compared with no fungicide application at $4083 \mathrm{~kg} \mathrm{ha}^{-1}$. The yield increase may be the result of the significantly lower leaf disease rating with fungicide compared with no application (2.2\% vs 3.8\%) and significantly lower FHB incidence (8.5\% vs $15.8 \%$ ) and severity (4.5\% vs $7.0 \%$ ) (data not presented). Disease development depends on the environmental conditions, and based on meta-analyses a reduction in disease is expected with a foliar fungicide [31]. However, a fungicide application may only reduce FHB by 50\% [31]. There were no significant differences for yield (Table 4) or other observed traits between the tile by foliar fungicide interaction (data not presented).

\subsubsection{Seed Treatment $\times$ Foliar Fungicide}

Although the main objective was to investigate interactions with water management there was an unexpected significant HRSW yield interaction for seed treatment by foliar fungicide in 2010, 2011, and the combined analysis 2009 to 2011 (Table 4). In 2010, the yield with both seed treatment and fungicide was higher than without seed and foliar fungicide treatments (Table 8). In 2011, the yield with seed treatment and fungicide was higher than no seed treatment with foliar fungicide. Overall, across the three years the seed treatment and foliar fungicide combination yielded significantly more than the three other treatments combinations. This seems to indicate that there is a synergism when seed treatment and fungicide application are both used.

\section{Conclusions}

With subsurface drainage there can be circumstances, like a dry growing season, when an open tile will not provide the highest yield compared with closed tile. However, controlling the water table (optimum management practice) resulted in significantly higher HRSW yield across years. In 2011, plants of Faller and Howard were taller, and Howard and Traverse had lower root disease severity, and in 2010 to 2011 Howard and Traverse had more leaf disease with open tile compared with closed tile. This seems to indicate that under certain environmental conditions there can be an interaction between cultivars and water management. Across years there was no difference in root disease, stand, number of spikes, plant height and yield response to application of seed treatments with closed or open tile. Only in 2010, there was a 3.7\% yield advantage with application of seed treatment with open tile compared with closed tile. Across years there was no positive yield response to application of foliar fungicides, but wheat yield with fungicide was 5\% higher than without foliar fungicide in 2010. There was no interaction across years between fungicide application and tile treatments. Across all years, the combination of seed treatment with foliar fungicide resulted in $4 \%$ higher yield compared with the other treatments.

In our study, the water table was set at the pre-determined level during the whole season. Future research should investigate crop yield response to actively managing the water table level throughout the season depending on the prevailing weather conditions. In our trial, we applied the fungicide regardless of the current weather outlook. There is a prediction model with probabilities that FHB may occur [1]. In future research, application of inputs should be done based on the likelihood of disease pressure.

Table 8. Wheat yields with different levels of seed treatments and foliar fungicide treatments in 2009 to 2011, Fargo, ND.

\begin{tabular}{|c|c|c|c|c|}
\hline & Foliar & \multicolumn{3}{|c|}{-----------Seed Yield----------- } \\
\hline Seed & Fungicide & & & 2009 \\
\hline \multirow[t]{2}{*}{ Treatment } & Treatment & 2010 & 2011 & to 2011 \\
\hline & & \multicolumn{3}{|c|}{--------------kg ha ${ }^{-1}$-------- } \\
\hline No & No & $4124 \mathrm{bc}^{\dagger}$ & $2480 a b$ & $3717 \mathrm{~b}$ \\
\hline No & Yes & $4226 \mathrm{ab}$ & 2347 c & $3709 \mathrm{~b}$ \\
\hline Yes & No & 4042 c & $2463 a b$ & $3702 \mathrm{~b}$ \\
\hline Yes & Yes & $4345 \mathrm{a}$ & 2523 a & 3854 a \\
\hline
\end{tabular}

${ }^{\dagger}$ Numbers within the same column with at one least similar letter are not significantly different at $P \leq 0.10$. 


\section{Acknowledgements}

Part of the funding for this research was received from the Minnesota Wheat and Promotion Council and the North Dakota Experiment Station. We gratefully acknowledge the help of Mr. Chad Deplazes, research specialist, and all summer interns assisting in this research.

\section{References}

[1] NDAWN (2014) Weather Data. North Dakota Agricultural Weather Network. North Dakota State University, Fargo. http://www.ndawn.ndsu.nodak.edu/

[2] Wiersma J.J., Sands, G.R., Kandel, H.J., Rendahl, A.K., Jin, C.X. and Hansen, B.J. (2010) Responses of Spring Wheat and Soybean to Subsurface Drainage in Northwest Minnesota. Agronomy Journal, 102, 1399-1406. http://dx.doi.org/10.2134/agronj2010.0055

[3] USDA-NASS (2015) http://www.nass.usda.gov/

[4] McMullen, M., Jones, R. and Gallenberg, D. (1997) Scab of Wheat and Barley: A Re-Emerging Disease of Devastating Impact. Plant Disease, 81, 1340-1348. http://dx.doi.org/10.1094/PDIS.1997.81.12.1340

[5] Sands, G. (2001) Agricultural Drainage: Soil Water Concepts. University of Minnesota Extension Service. http://www.extension.umn.edu/agriculture/water/agricultural-drainage/soil-water-concepts/

[6] Jin, C.X., Sands, G.R., Kandel, H.J., Wiersma, J.J. and Hansen, B.J. (2008) Influence of Subsurface Drainage in Soil Temperature in a Cold Climate. Journal of Irrigation and Drainage Engineering, 134, 83-88. http://dx.doi.org/10.1061/(ASCE)0733-9437(2008)134:1(83)

[7] Chieng, S.T., Keng, J. and Driehuyzen, M.G. (1987) Effects of Subsurface Drainage and Subirrigation on the Yields of Four Crops. Canadian Agricultural Engineering, 29, 21-26.

[8] Kandel, H.J., Brodshaug, J.A., Steele, D.D., Ransom, J.K., DeSutter, T.M. and Sands, G.R. (2013) Subsurface Drainage Effects on Soil Penetration Resistance and Water Table Depth on a Clay Soil in the Red River of the North Valley, USA. Agricultural Engineering International: CIGR Journal, 15, 1-10.

[9] Nelson, K.A., Meinhardt, C.G. and Smoot, R.L. (2012) Soybean Cultivar Response to Subsurface Drainage and Subirrigation in Northeast Missouri. Crop Management, 11, 1. http://dx.doi.org/10.1094/CM-2012-0320-03-RS

[10] Nelson, K.A. and Smoot, R.L. (2012) Corn Hybrid Response to Water Management Practices on Claypan Soil. International Journal of Agronomy, 2012. http://dx.doi.org/10.1155/2012/925408

[11] Nelson, K.A. and Meinhardt, C.G. (2011) Soybean Yield Response to Pyraclostrobin and Drainage Water Management. Agronomy Journal, 103, 1359-1366. http://dx.doi.org/10.2134/agronj2011.0112

[12] Nelson, K.A., Smoot, R.L. and Meinhardt, C.G. (2011) Soybean Response to Drainage and Subirrigation on a Claypan Soil in Northeast Missouri. Agronomy Journal, 103, 1216-1222. http://dx.doi.org/10.2134/agronj2011.0067

[13] McMullen, M. and Adhikari, T. (2009) PP-1249. Fungal Leaf Spot Diseases of Wheat: Tan Spot, Stagonospora nodorum Blotch and Septoria tritici Blotch. NDSU Extension Service, Fargo, 1-6.

http://www.ag.ndsu.edu/pubs/plantsci/pests/pp1249.pdf

[14] Bechtel, D.B., Kaleikau, L.A., Gaines, R.L. and Seitz, L.M. (1985) The Effects of Fusarium graminearum Infection on Wheat Kernels. Cereal Chemistry, 62, 191-197.

[15] Ransom, J.K. and McMullen, M.P. (2008) Yield and Disease Control on Hard Winter Wheat Cultivars with Foliar Fungicides. Agronomy Journal, 100, 1130-1137. http://dx.doi.org/10.2134/agronj2007.0397

[16] Harding, H. (1978) Root Rot of Cereals-Everyone’s Problem? Canada Agriculture, 23, $25-29$.

[17] Machacek, J.E. (1943) An Estimate of Loss in Manitoba from Common Root-Rot in Wheat. Scientia Agricola, 24, 7077.

[18] Stack, R.W. and McMullen M.P. (1991) Effects of Fungicide Seed Treatments on Common Root Rot of Spring Wheat and Barley. North Dakota Farm Research, 49, 13-16.

[19] Wiersma, J.J. and Kandel, H.J. (2004) The Response of Fusarium graminearum-Infected Seed of Hard Red Spring Wheat to Vitavax Extra RTU and Dividend XL Seed Treatments. Plant Health Progress. http://dx.doi.org/10.1094/PHP-2004-0416-01-RS

[20] Zadoks, J.C., Chang, T.T. and Konzak, C.F. (1974) A Decimal Code for the Growth Stages of Cereals. Weed Research, 14, 415-421.

[21] USDA-NRCS (2012) Soil Survey of Cass County. USDA-NRCS, Washington DC.

[22] Anderson, J., Wiersma, J., Linkert, G., Reynolds, S. and Springer, C. (2010) Varietal Trial Results: Wheat, Hard Red Spring. Minnesota Agricultural Experiment Station, University of Minnesota, Minneapolis and Saint Paul. 
http://www.maes.umn.edu/sites/maes.umn.edu/files/wheat_spring_2009.pdf

[23] Ransom, J.K., Mergoum, M. and Simsek, S. (2009) A-574. North Dakota Hard Red Spring Wheat Variety Trial Results for 2009. NDSU Extension Service, Fargo.

[24] Wiersma, J.J. and Ransom, J.K. (2005) The Small Grains Field Guide. North Dakota State University Extension Publication A290 and University of Minnesota Extension Service Publication 0788-S, Fargo and St. Paul.

[25] Nowatzki, J., Halley, S., Van Ee, G., Hofman, V., McMullen, M., Hollingsworth, C. and Ruden, B. (2013) AE1314. Ground Application of Fungicide for the Suppression of Fusarium Head Blight in Small Grains. NDSU Extension Service, Fargo, 1-4. http://www.ag.ndsu.edu/pubs/ageng/machine/ae1314.pdf

[26] Stack, R.W. and McMullen, M. (1999) PP-785. Root and Crown Rots of Smalls Grains. North Dakota State University, Fargo. http://www.ag.ndsu.edu/pubs/plantsci/smgrains/pp785w.htm

[27] Tobias, D.J., Stack, R.W., Puri, K.D., Riveland, N. and Zhong, S. (2009) Reactions of Hard Red Spring Wheat to Common Root Rot under Field Conditions of Northern United States of America. Euphytica, 167, 165-172. http://dx.doi.org/10.1007/s10681-008-9853-8

[28] Stack, R.W. and McMullen, M.P. (2011) PP-1095. A Visual Scale to Estimate Severity of Fusarium Head Blight in Wheat. North Dakota State University Extension Publication, Fargo. http://www.ag.ndsu.edu/pubs/plantsci/smgrains/pp1095.pdf

[29] Poole, C.A., Skaggs, R.W., Cheschier, G.M., Youssef, M.A. and Crozier, C.R. (2013) Effects of Drainage Water Management on Crop Yields in North Carolina. Journal of Soil and Water Conservation, 68, 429-437. http://dx.doi.org/10.2489/jswc.68.6.429

[30] Cook, R.J., Weller, D.M., El-Banna, A.Y., Vakoch, D. and Zhang, H. (2002) Yield Response of Direct-Seeded Wheat to Rhizobacteria and Fungicide Seed Treatments. Plant Disease, 86, 780-784. http://dx.doi.org/10.1094/PDIS.2002.86.7.780

[31] Willyerd, K.T., Li, C., Madden, L.V., Bradley, C.A., Bergstrom, G.C., Sweets, L.E., McMullen, M., Ransom, J.K., Grybauskas, A., Osborne, L., Wegulo, S.N., Hershman, D.E., Wise, K., Bockus, W.W., Groth, D., Dill-Macky, R., Milus, E., Esker, P.D., Waxman, K.D., Adee, E.A., Ebelhar, S.E., Young, B.G. and Paul, P.A. (2012) Efficacy and Stability of Integrating Fungicide and Cultivar Resistance to Manage Fusarium Head Blight and Deoxynivalenol in Wheat. Plant Disease, 96, 957-967. http://dx.doi.org/10.1094/PDIS-09-11-0763

\section{Abbreviations}

HRSW = Hard Red Spring Wheat;

RRV = Red River Valley;

FHB $=$ Fusarium Head Blight 